DOI https://doi.org/10.30525/978-9934-588-81-5-2.23

\title{
UNSOLVED ISSUES OF CHILD VACCINATION \\ AND MARKETING INVESTIGATION OF THE AVAILABILITY OF TUBERCULOSIS VACCINE IN UKRAINE
}

\author{
Krychkovska A. M. \\ PhD in Pharmacy Sciences, Associate Professor, \\ Associate Professor at the Department of Technology of Biologically \\ Active Substances, Pharmacy and Biotechnology \\ Lviv Polytechnic National University \\ Zayarnyuk N. L. \\ PhD in Pharmacy Sciences, Associate Professor, \\ Associate Professor at the Department of Technology of Biologically \\ Active Substances, Pharmacy and Biotechnology \\ Lviv Polytechnic National University \\ Lopatynska O. I. \\ PhD in Pharmacy Sciences, Associate Professor, \\ Associate Professor at the Department of Technology of Biologically \\ Active Substances, Pharmacy and Biotechnology \\ Lviv Polytechnic National University \\ Bolibruh L. D. \\ PhD in Chemistry Sciences, Associate Professor, \\ Associate Professor at the Department of Technology of Biologically \\ Active Substances, Pharmacy and Biotechnology \\ Lviv Polytechnic National University \\ Novikov V.P. \\ Doctor in Chemistry Sciences, Professor, \\ Head of the Department of Technology of Biologically Active Substances, \\ Pharmacy and Biotechnology \\ Lviv Polytechnic National University \\ Lviv, Ukraine
}

According to WHO statistics, about 9 million people worldwide suffer from tuberculosis (TB) each year. Among them, only 6 million patients are treated. Approximately 1.7 million TB deaths occurred each year [3, 4]. The prevention of $\mathrm{TB}$ as the main way to reduce the prevalence of the disease by interrupting the transmission of the pathogen from an infected person to the healthy people is an immediate and main goal of national healthcare programs in many countries $[2,3,4,6]$. The research aimed was to study the problems of the TB vaccination process in children in Ukraine, to summarize statistics on the incidence of TB in children and adults, to 
highlight and investigate the steps of the vaccination process where inconsistencies arising, and to conduct marketing research on vaccines availability at the pharmaceutical market in Ukraine.

In Ukraine, in 2019, the Child Immunization Schedule of (CIS) was corrected and adjusted for completely harmonize with the CISs in the EU and the USA [5]. According to the renewal CIS, children should be vaccinated for TB (Bacille Calmette-Guérin - BCG) on the 3-5 days after birth for the first time, and revaccinated at age 7 years old, as it was a long time in Ukraine, is no longer carried out. The newborns who have certain developmental abnormalities, on 1-2 days of life are transferred to specialized children's hospital's department, where vaccination is not carried out because BCG vaccines are not available at these departments. This vaccine is also not available in children's outpatient clinics because children at the 7 years old are no longer vaccinated. Every year, specialists of the State Institution «Center for Public Health of the Ministry of Healthcare of Ukraine» and the State Institution «Center for Medical Statistics of the Ministry of Healthcare of Ukraine» has published an analytical and statistical guideline «Tuberculosis in Ukraine» and others documents concerning the incidence of TB in Ukraine [5]. We have investigated the statistics on the TB incidence for the last three years (tabl. 1).

Table 1

Statistics on the TB incidence in Ukraine *

\begin{tabular}{|c|c|c|c|}
\hline Nosology/years & $\mathbf{2 0 1 8}^{*}$ & $\mathbf{2 0 1 9}^{*}$ & $\mathbf{2 0 2 0}^{*}$ \\
\hline $\begin{array}{c}\text { Pulmonary TB (ICD-10 Codes A15.0 - 3, } \\
\text { A16.0 - 2, A19 - partway) }\end{array}$ & 7668 & 7461 & 6238 \\
\hline $\begin{array}{c}\text { Extra pulmonary TB (ICD-10 Codes A15.0 - 3, } \\
\text { A16.0 - 2, A19 - partway) }\end{array}$ & 638 & 642 & 500 \\
\hline The total number of TB cases (ICD-10 Codes) & 8306 & 8103 & 6738 \\
\hline Relapses & 1359 & 1243 & 1061 \\
\hline New cases & 5254 & 5309 & 4527 \\
\hline
\end{tabular}

*1st quarter of the current year

According to statistics, the dynamics of TB incidence among adults tend to decrease relative to relapses, but for new cases these dynamics are unstable. It should be noted that the adult population of Ukraine is vaccinated during the first days of life and revaccinated at 7 years old. The coverage of the adult population with preventive, fluorographic examinations continues to decrease - up to $45.9 \%$ in 2017 , and the part of children aged 4-14 years with tuberculin testing decreased from $64.4 \%$ in 2012 to $49.7 \%$ in 2017 . The number of children younger than 1 year of age, who received BCG prophylactic vaccination decreased to $83.6 \%$ in 2017 , as well as the number of children older than 7 years - to $46.0 \%$ in 2017 [1]. The incidence rate of TB in children aged 0-17 years decreased by $15 \%$ in 
2014 compared to 2013. However, the incidence rate of TB among children is increased by $2.9 \%$ in 2018 compared to 2014. In 2014, the incidence rate was 10.1 per 100000 people, and in $2018-10.4$ per 100000 people, or 770 and 788 in absolute indicators, respectively $[2,6]$. Therefore, the question on the expediency of withdrawal of BCG revaccination in Ukraine for children at the 7 years old and, if necessary, at 14 years old is arising. In such a situation, the solving of the problem of supplying children's departments of health care establishments (HCE) with the BCG vaccine requires a special approach.

In Ukraine, the CIS from 2019 provides for vaccination against 10 diseases. All vaccinations before the age of 18 are free. Also, adults at risk, including healthcare professionals, students, military, teachers, can get free vaccinations against measles, rubella, and mumps. But, when the absence of BCG vaccine supplying into outpatient pediatric departments of HCE is observed, the purchase of them by their own expense is needed. The marketing analysis of the BCG vaccine assortment in Ukraine, both domestic and foreign manufacturing, allowed to establish their availability on the State Drugs List and price in pharmacies (tabl. 2).

Table 2

The availability of the BCG vaccine and tuberculin in the State Drugs List

\begin{tabular}{|c|c|c|c|c|c|}
\hline 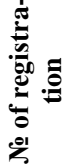 & 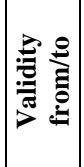 & $\begin{array}{c}\text { Name/type of } \\
\text { formulated prepa- } \\
\text { ration }\end{array}$ & $\begin{array}{c}\text { Composition } \\
\text { of } \\
\text { active } \\
\text { substances }\end{array}$ & Manufacture & $\begin{array}{c}\text { Appli- } \\
\text { cant }\end{array}$ \\
\hline 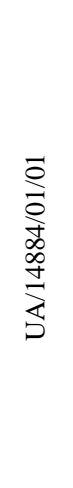 & 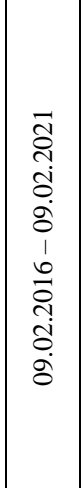 & $\begin{array}{l}\text { Vaccine for the TB } \\
\text { prevention; live, dry; } \\
\text { BCG-10. Powder } \\
\text { and solvent for } \\
\text { suspension for } \\
\text { intradermal injec- } \\
\text { tion, } 0.5 \mathrm{mg} \text { (10 } \\
\text { doses) of powder in } \\
\text { a glass ampoule and } \\
1 \mathrm{ml} \text { of solvent } \\
\text { (isotonic sodium } \\
\text { chloride solution) in } \\
\text { another glass am- } \\
\text { poule, № } 5 \text { in a } \\
\text { cardboard box }\end{array}$ & $\begin{array}{c}\text { one dose }(0.1 \mathrm{ml}) \text { of } \\
\text { vaccine contains } 50 \mu \mathrm{g} \text { of } \\
\text { semi-dry mass of BCG } \\
\text { mycobacteria, from } \\
150000 \text { to } 600000 \text { live } \\
\text { BCG mycobacteria }\end{array}$ & $\begin{array}{c}\text { BIOMED- } \\
\text { LUBLIN, } \\
\text { Joint-Stock } \\
\text { Company } \\
\text { (vaccine } \\
\text { manufacturer), } \\
\text { Poland } \\
\text { POLPHARM } \\
\text { A S.A.; Phar- } \\
\text { maceutical } \\
\text { Works (sol- } \\
\text { vent manufac- } \\
\text { turer), Poland }\end{array}$ & $\begin{array}{c}\text { BIOM } \\
\text { ED- } \\
\text { LUBL } \\
\text { IN, } \\
\text { Joint- } \\
\text { Stock } \\
\text { Com- } \\
\text { pany, } \\
\text { Poland }\end{array}$ \\
\hline
\end{tabular}




\begin{tabular}{|c|c|c|c|c|c|}
\hline 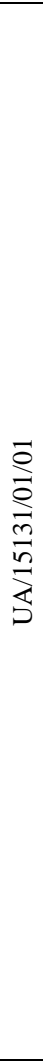 & 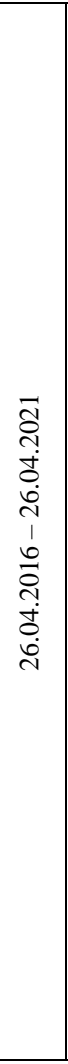 & $\begin{array}{l}\text { BCG vaccine, SSI } \\
\text { Vaccine for TB } \\
\text { prevention. } \\
0.75 \mathrm{mg} \text { of powder } \\
\text { and solvent for } \\
\text { suspension for } \\
\text { injection; } 5 \text { vials of } \\
\text { powder and } 5 \mathrm{vials} \\
\text { of solvent on } 1 \mathrm{ml} \text { in } \\
\text { a cardboard box; } 10 \\
\text { vials of powder and } \\
10 \text { vials of solvent } \\
\text { on } 1 \mathrm{ml} \text {, placed in } \\
\text { separate cardboard } \\
\text { boxes }\end{array}$ & 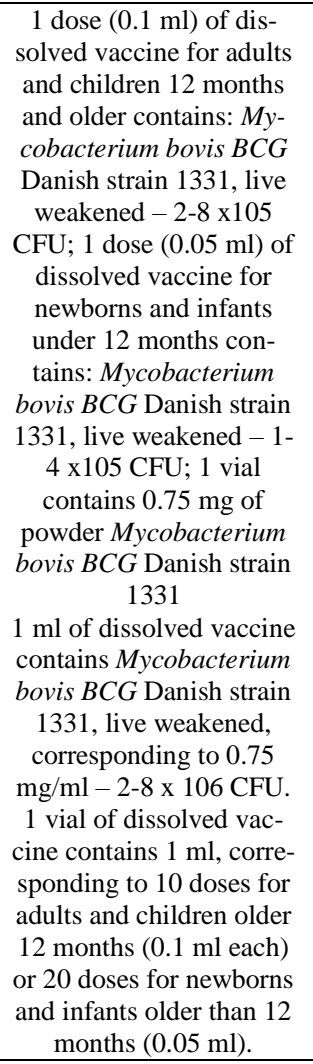 & $\begin{array}{l}\text { Statens Serum } \\
\text { Institute, } \\
\text { Denmark }\end{array}$ & $\begin{array}{l}\text { Stat- } \\
\text { ens } \\
\text { Serum } \\
\text { Insti- } \\
\text { tute, } \\
\text { Den- } \\
\text { mark }\end{array}$ \\
\hline \multicolumn{6}{|c|}{ Tuberculin: } \\
\hline 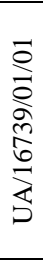 & 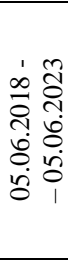 & $\begin{array}{c}\text { Tuberculin PPD } \\
R T 23 \text { SSI. Solution } \\
\text { for injection } 2 \\
\text { TO/0.1 ml on } 1.5 \\
\mathrm{ml} \text { of solution }(15 \\
\text { doses) in a vial; } 1 \\
\text { or } 10 \text { vials in a } \\
\text { cardboard box }\end{array}$ & $\begin{array}{l}1 \text { dose }(0.1 \mathrm{ml}) \text { contains: } \\
0.04 \mu \mathrm{g} \text { of tuberculin PPD } \\
\text { RT } 23(2 \mathrm{TO}) .1 \text { vial }(1.5 \\
\text { ml) contains: } 15 \text { doses of } \\
\text { Tuberculin PPD RT } 23 \\
\text { SSI }(2 \mathrm{TO} / 0.1 \mathrm{ml})\end{array}$ & $\begin{array}{l}\text { AJ Vaccines } \\
\text { A/S, Denmark }\end{array}$ & $\begin{array}{l}\text { Stat- } \\
\text { ens } \\
\text { Serum } \\
\text { Insti- } \\
\text { tute, } \\
\text { Den- } \\
\text { mark }\end{array}$ \\
\hline 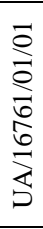 & 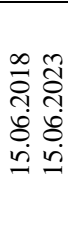 & $\begin{array}{c}\text { Tuberculin PPD } \\
R T 23 \text { SSI. Solution } \\
\text { for injection } 2 \\
\text { TO/0.1 ml on } 1.5 \\
\mathrm{ml} \text { in bulk: in vials } \\
\text { № } 1300-1400 \text { in a } \\
\text { plastic bag }\end{array}$ & $\begin{array}{l}1 \text { dose }(0.1 \mathrm{ml}) \text { contains: } \\
0.04 \mu \mathrm{g} \text { of tuberculin PPD } \\
\text { RT } 23 \text { ( } 2 \text { TO). } 1 \text { vial }(1.5 \\
\text { ml) contains: } 15 \text { doses of } \\
\text { Tuberculin PPD RT } 23 \\
\text { SSI }(2 \mathrm{TO} / 0.1 \mathrm{ml})\end{array}$ & $\begin{array}{l}\text { AJ Vaccines } \\
\text { A/S, Denmark }\end{array}$ & $\begin{array}{l}\text { Stat- } \\
\text { ens } \\
\text { Serum } \\
\text { Insti- } \\
\text { tute, } \\
\text { Den- } \\
\text { mark } \\
\end{array}$ \\
\hline
\end{tabular}




\begin{tabular}{|c|c|c|c|c|c|}
\hline 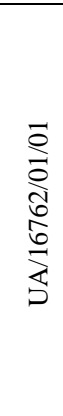 & 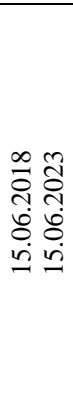 & $\begin{array}{c}\text { Tuberculin PPD } \\
R T 23 \text { SSI. Solution } \\
\text { for injection } 2 \\
\text { TO/0.1 ml; on } 1.5 \\
\text { ml of solution ( } 15 \\
\text { doses) in a vial; } 1 \\
\text { vial complete with } \\
15 \text { self-locking } \\
\text { syringes in contour } \\
\text { packaging or } \\
\text { without contour } \\
\text { packaging in a } \\
\text { cardboard box }\end{array}$ & $\begin{array}{c}1 \text { dose }(0.1 \mathrm{ml}) \text { contains: } \\
0.04 \mu \mathrm{g} \text { of tuberculin PPD } \\
\text { RT } 23(2 \mathrm{TO}) ; 1 \text { vial }(1.5 \\
\text { ml contains: } 15 \text { doses of } \\
\text { Tuberculin PPD RT } 23 \\
\text { SSI }(2 \mathrm{TO} / 0.1 \mathrm{ml})\end{array}$ & $\begin{array}{c}\text { LUMIER } \\
\text { PHARMA } \\
\text { Ltd, Ukraine }\end{array}$ & $\begin{array}{c}\text { LUMI } \\
\text { ER } \\
\text { PHAR } \\
\text { MA } \\
\text { Ltd, } \\
\text { Ukrain } \\
\text { e }\end{array}$ \\
\hline
\end{tabular}

The cost of tuberculin in pharmacies in Ukraine ranged from 176 to 189 UAH. or $~ 6$ Euro. The cost of the BCG vaccine has not been established, as it is delivered directly only to maternity hospitals. Only the Uro-BCG vaccine, which costs UAH 3000 or $\sim 95$ Euro, is available at pharmacies. In some private HCE, vaccination is offered as a service with a pediatrician's examination and its cost is from UAH 100 until UAH 1000. However, BCG vaccination is not offered.

Conclusions. It is necessary to introduce a new approach to the BCG vaccination process in newborns who are transferred during the first days of life to specialized departments of HCE and are not vaccinated in maternity hospitals. Understanding the problems in society met by the patient can help not only to solve some of them but also to consciously approach the need for vaccination and revaccination of children. Early and timely detection of TB patients is a necessary condition for their rapid and complete treatment and is decisive to prevent and reduce the spread of infections, as patients with advanced pulmonary TB are epidemically dangerous.

\section{References:}

1. Analytical and statistical information on tuberculosis. Center for Public Health of the Ministry of Health of Ukraine, available at: http:// https://phc.org.ua/kontrol-zakhvoryuvan/tuberkuloz/statistika-ztb/analitichno-statistichni [in ukr.]

2. Feshchenko Yu.I., Melnyk V.M., Matusevych V.G. The situation with tuberculosis in Ukraine in the period of health care reform, available at: http://amnu.gov.ua/sytuacziya-z-tuberkulozu-v-ukrayini-v-periodreformuvannya-ohorony-zdorov-ya/3/ [in ukr.]

3. Global Tuberculosis Report, 2019, available at: https://reliefweb.int/ report/world/global-tuberculosis-report-2019 
4. Madhukar P. Tracking TB Vaccination Policies and Practices Through Space and Time, available at: Https://Naturemicrobiology community.nature.com/posts/15729-tracking-tb-vaccination-policies-andpractices-through-space-and-time

5. On changes to the preventive vaccinations schedule in Ukraine. Order of Ministry of Health care in Ukraine (№947, 18.05.2018), available at: https://moz.gov.ua/article/ministry-mandates/nakaz-moz-ukraini-vid18052018--947-pro-vnesennja-zmin-do-kalendarja-profilaktichnihscheplen-v-ukraini [in ukr.]

6. Ustynov A.V. Tuberculosis in Ukraine: the incidence rate is declining, available at: https://www.umj.com.ua/article/139407/tuberkuloz-vukrayini-riven- zahvoryuvanosti-znizhuyetsya [in ukt.].

DOI https://doi.org/10.30525/978-9934-588-81-5-2.24

\title{
АСПЕКТИ ДОСЛІДЖЕННЯ CALTHA PALUSTRIS
}

\author{
Лях В. P. \\ аспірант кафедри технологї біологічно активних сполук, \\ фармаиії та біотехнології \\ Національний університет «Львівська політехніка»
}

Конечна Р. T.

кандидат фармацевтичних наук,

дочент кафедри технології біологічно активних сполук, фармачії та біотехнологї

Національний університет «Львівська політехніка»

Новіков В. П.

доктор хімічних наук,

завідувач кафедри технологї біологічно активних сполук, фармачії та біотехнології

Національний університет «Львівська політехніка» м. Львів, Украӥна

Калюжниця болотна (Caltha palustris) - це багаторічна трав'яниста рослина, що використовується як декоративна, харчова та лікарська рослина.

Caltha palustris поширена у всіх високогірних районах Українських Карпат. Росте на берегах водойм, вологих луках, озерах, заболо- 